\title{
PERSPECTIVES ON THE CONTRIBUTION OF HigHER EDUCATION TO EDUCATION AS A HUMANITARIAN RESPONSE
}

\author{
Colin Brock \\ Department of Education, University of Oxford
}

"The future depends on what we do in the present."

Mahatma Gandhi

\begin{abstract}
The context assumed in this argument is that of a potential catastrophe for humanity and the global environment within a century or two. The contention is that education in a radical form, centrally involving universities and other higher education institutions (HEls), is the most likely weapon available to mankind that can avert such a disastrous scenario. The discussion focuses on the crucial issue of scale and the need to move from national and even provincial level policy and practice to that of local communities. This involves radical reform of the content and delivery of schooling through the involvement of universities with local institutions of delivery. Recourse is made to important recent sources promoted by UNESCO focusing on these crucial partnerships between universities, schools and communities, linking the global with the local through information and communications technology (ICT) in the interests of education as a humanitarian response.
\end{abstract}

\section{Introduction}

It is first necessary, for the purposes of this paper, to present definitions of 'higher education' and 'education as a humanitarian response' as I perceive them. Otherwise the interpretation of the discourse will depend on the many definitions of both that are held by the collective readership. In colloquial terminology the aim is to enable the reader to be clear from the outset as to where the narrative is 'coming from'.

Higher education is often conventionally equated with the tertiary sector, and especially universities. If words are to be taken on their face value then tertiary must mean everything that is post-secondary. That is the simple logical definition to be adopted here, but as it stands it resides only in the realm of formal education. This is unrealistic, since a range of organised educational provision resides in the non-formal realm that is certainly postsecondary in nature, not to mention informal education. In the modern era millions of people, in all kinds of locations from affluent western suburbia to subsistence communities in Africa, learn informally from global media ranging from radio to mobile phones. People of all ages are susceptible to the acquisition of knowledge and skills through informal learning. Some elements of this will be of the order of tertiary level learning, but may be acquired by involuntary means. Such a perspective may suggest that the contribution of higher education to any community is both actually and potentially much greater than it is conventionally assumed to be.

Education as a humanitarian response is conventionally seen in terms of 'education for emergencies' and 'education for special needs'. As with higher education, the reality can be much more extensive; even universal. Clearly it is humane to provide elements of educational support to those suffering from disasters, be they natural, man-made or a combination of both. A humanitarian response to educational need requires it to be appropriate to that need in respect of every individual at any particular time and place. In terms of both an individual and a community - whether it be local, national or global - the need is to assist stability allied to sustainable development (Brock, 2011). That is to say, the notion of an education appropriate to need is universal but the form it may take may vary considerably from one individual to another as well as from community to community.

In addition to the need for sustainability at all levels from the individual to the global is the issue of survival on a finite space, planet Earth. We are now all living at a time when credible science indicates clearly that the human species has created an impending environmental catastrophe. This is expressed in the closing paragraph of Piers Brizony's Science: The Definitive Guide (2011):

${ }^{1}$ Correspondence can be directed to: drcbrock@hotmail.com 


\section{COLIN BROCK}

Whatever the possible outcomes, for the planet or for the universe, none of these grand-scale events can conceivably matter to us, our descendants, or even the creatures we might become some thousands or even tens of millions of years into the future. What will count are the decisions that we make during the current, extraordinarily brief spark of time during which technological ingenuity has become balanced almost exactly against the environmental stresses caused by the same ingenuity. The balance will tip, one way or another, in decades or centuries, not eons. A new kind of science might well be advised to take into account the vast stretch of opportunity that exists between today and when our sun shines its last. If we think like sentients of an infinite cosmos instead of like nervous beasts scuttling on the surface of a tiny, overcrowded, sphere of rock - if we aspire to live as long as our own star continues to shine - we might have a chance at least, of making it through the next century (p.203).

So-called 'climate change deniers' would dispute this of course, claiming it to be mere scare-mongering by academics hell bent on disrupting the comfortable lives of the affluent. But as Robin McKie (2011) has rightly pointed out in The Observer, science itself is based on skepticism. It challenges the conventional wisdom. Brizony's own challenge in the final lines of his book, quoted above, is a challenge to education, as predicted by the novelist H.G. Wells succinctly over a century ago: 'Human history becomes more and more a race between education and catastrophe'. Any educational action that attempts to meet this challenge will necessarily be 'education as a humanitarian response', for if it succeeds, humanity will have been preserved. If not, then humanity will have been shattered. The eminent historian Richard Aldrich (2010) sees history as a continuum involving not just the past but the present and the future as well. Not surprisingly he is exercised about what is happening:

We live on an overpopulated spaceship whose life support systems are running out. Our major concern is no longer the origin, but rather the death of species - especially our own (p.1).

It is the contention of this discourse that a successful response, on the part of education, to the doomsday challenges of Wells, Brizony and others has to be led by tertiary education, with universities in the vanguard. Only they have the means to meet the challenges of education and of scale that are already upon us. As Aldrich has it:

Existing aims such as education for salvation, education for the state and education for progress must be modified, replaced even, by the goal of education for survival (ibid).

\section{The Challenge of Scale}

The challenge of scale has, in the literature of educational studies, been largely to do with the problems and prospects of small countries and territories from Brock (1974) to Crossley, Bray and Packer (2011). This is still a significant issue for about 40 per cent of the countries in the world. But it has also made a small contribution to the wider literature of comparative and international education (Bray \& Murray Thomas, 1995) and Brock (2011). The realisation is beginning to dawn that the fixation of much in this field with the national scale of reference has not served us well. What we need is to perceive, analyse and understand the geography of educational reality. That is to say, what actually happens on the ground in every locality. There is considerable disparity in the application of national policies on education at the local level. This is clearly seen in respect of the influence of market-oriented policies on school choice, see Griffin (2001) and Hamnett and Butler (2011). Neo-liberal policies of quasi-disengagement from the state inevitably lead to increased disparity in terms of a range of indicators relating to education. Yet the majority of governments remain obsessed with comparisons of academic achievement at the national scale of reference, such as TIMMS, PISA and university rankings.

All that is to do with geographical or spatial scale, but even more neglected in the literature is the issue of historical or temporal scale. There are exceptions but none of the order to inform Brizony's challenge, and that of Martin, (2011) for much more intensive and intelligent action by all societies in the interest of global human survival and sustainable development beyond the twenty-first century. Martin begins:

Like the tension building in a suspense novel, the dangers from future climate change are racketing up year after year. The world's media have become increasingly full of images of 
collapsing ice-shelves, stranded polar bears, raging hurricanes, lands stricken by drought, fires sweeping across southern Australia and deserts spreading. The ice-caps are melting in both the Arctic and the Antarctic. But all this is only an overture to trouble on a much grander scale. The runaway transformation of the Earth's climate may become the worst crisis of human history (p.28).

The work of Akin Mabogunje (1980) is a good starting point from which to appreciate the significance of spatial scale in development. His book The Development Process: A Spatial Perspective is a seminal contribution to the literature. One of the outstanding geographers of his generation, Mabogunje recognises the dynamic nature of spatial structures and spatial organisations. The former, he argues, tend to show a high degree of constancy and consistency over time. He goes on to indicate that to have a coherent spatial structure members of a society must know what to expect so: 'spatial structure thus tends to reflect ideal patterns of behaviour which are socially set and which may in fact be formally determined by rules, regulations and legislation' (p. 55). This will include formal education regulations, which on paper require the participation of all citizens of a country in a compulsory phase of schooling. This brings us to the issue of formal education systems, how they have developed and what they are for. It also brings us back to universities and their formative influence.

\section{Universities and the Nature of Systems of Schooling}

In the modern era of nation states, generally recognised as emerging in Europe from the seventeenth century onwards to the nineteenth, schools developed in the image of existing universities. They formed part of Dodgshon's (1987) transition in Europe from political control over groups of people to control also over regulated territory. Knowledge has always meant power and even every small emerging polity, more than 300 alone in proto-Germany, experienced a power battle between the merchants, the church and the government to control universities (Brock, 2010). Why is this of significance for people and their education all over the world in the twenty-first century? It is because the knowledge economy is now of massive global influence, and the universities and other higher education institutions have unparalleled expertise to operate spatially in increasingly sophisticated ways. They have the potential to make a fundamental and unrivalled contribution to popular education in the interest of survival and sustained development on planet Earth within the time-frame of Brizony's challenge, the twenty-first century.

Yet universities, as has been mentioned, even those that are privately operated, are themselves under pressure from the spatial parameters of politicians. They can only be as good as the school systems that feed them, and these systems are generally subject to some kind of national curriculum. Governments can be disingenuous with regard to their degree of commitment to the efforts of international bodies they purport to support in their efforts to engender the critical and creative thinking that is urgently needed. For example, the UK Government is reported thus in the UNESCO 2010 publication Education for Sustainable Development:

Sustainable development is a way of thinking about how we organize our lives and work including our education system - so that we don't destroy our most precious resource, the planet...It must be much more than recycling bottles or giving money to charity. It is about thinking and working in a profoundly different way (p.42).

Yet, as alluded to above, like most governments in the more developed countries, such as full members of the OECD, the UK government does quite the opposite in respect of the school curriculum where so-called 'core' subjects are afforded higher status at the expense of others. In practice it means affording a higher status to instrumentality over creativity, part of which is 'thinking and working in a profoundly different way'. It is this curricular inertia, based on an outdated conventional wisdom that attracted the ire of Sir Ken Robinson in his celebrated TED presentation in Los Angeles in 2006. Robinson rightly extended his criticism to the tertiary sector in that universities operate a formulaic admissions system based on success in certain areas of the curriculum in their own image. Or, in other words as he put it, 'the ultimate aim of school systems is to produce university professors who are in fact 'simply another form of life', nothing more, nothing less.

This view is close to that of David Orr (1994) who castigates the schools and universities, and therefore governments, for supporting and rewarding what he calls 'mere intellectual cleverness' at the expense of intelligence. This is exactly what Brizony has in mind in the quotation above when he refers to our 'technological ingenuity becoming balanced almost exactly against the environmental stresses caused by the same ingenuity'. Real technological ingenuity at the highest level is of course the preserve of the really outstanding, but with regard to the bulk of the output of the universities, Orr describes them as 'minds ignorant of their own ignorance', and goes on to say:

As a result, an increasing percentage of human intelligence must attempt to undo a large part of what mere intellectual cleverness has done carelessly and greedily (p.17). 


\section{COLIN BROCK}

By 'human intelligence' in the context of this quotation, Orr means the formal education system from its entry point to whatever exit point any particular individual may experience. It means the curriculum and the aforementioned UK government's not 'thinking and working in a profoundly different way'.

What does this mean in terms of temporal scale and in terms of the work of schools and colleges? The duration of schooling in most countries with universal primary and secondary provision is about ten years (that is approximately 5-15 in the age range). At the time of writing (January 2012) there is little sign of that changing. This means that those entering primary school now will not leave university, if they go there, until about 2022. Their children will do so around 2045. This likely means a whole generation before significant curricular change, but as Aldrich rightly points out: 'While the young should certainly be educated as to the importance of survival, the danger is too immediate to be postponed to another generation' (Aldrich, 2010, p. 12). Do governments realise this? It would appear not. Despite the UK government's statement above, it is, in reality, stuck in a reactionary time warp dominated by a competitive nationalism exacerbated by flawed cross-national comparisons of student achievement. This is a point highlighted by Lynne Davies (2005) in her article 'Education in the Twenty-First Century: Conflict, Reconciliation and Reconstruction. She goes on to warn:

We have a crisis: not of globalisation, not of the economy but of something that transcends those. It is a crisis of the refusal to see what is happening to learning in our societies (p. 358).

It would seem that the necessary radical reform will not be coming from governments tied to nationalism, many of whom control the research and curricula of their universities as well as their schools. However, in some parts of the world universities have managed to maintain a degree of independence and are therefore the main hope for radical reform of the compulsory sector, and a return to the internationalism of their origins.

\section{Universities: The Last Chance Solution for Radical Reform}

In a sense universities have created the problem for which they now appear to be the main hope of a solution. This was not planned of course, but simply a consequence of universities pre-dating the emergence of formal school systems whose nature, content and sequence were necessarily appropriate for the onward transfer of pupils to be students in universities. In fact, the earliest formal schools in modern Europe predated national systems and were to do with the Christian churches, Catholic and Orthodox. Such early schools were initially for boys only, for educating and training choristers and then selecting for the priesthood. The curriculum was dominated by classics, philosophy and theology. Sciences and modern languages were treated with suspicion until the influence of the industrial revolution and international trading. However a recent study (Elliot \& Daniels, 2010) have revealed that curricular diversification in English grammar schools began to occur much earlier than was thought. In particular: 'Dissenting schools have often been associated with the introduction of "modern" subjects including mathematics, geography, natural philosophy and modern languages' (p. 16). It was from the early to middle nineteenth century that universities in Europe and North America began to require new students to be proficient in certain new subjects as well as old on leaving school. With massification of secondary schooling in the west the so-called 'European idea of education' (Mallinson, 1980) became the template and spread through colonial conquest and neo-colonial appropriation by the turn of the twentieth-century. Such massification was also associated with credentialism, which in turn required examinations, qualifications and selection (Hopper, 1968). The ultimate selection is that for entry to university. To different degrees from country to country specialisation emerged in respect of qualification gained at school. Oxenham (1984) was sufficiently alarmed to title his key work 'Education versus Qualifications', following his colleague Ronald Dore's radical analysis of this dangerous trend 'The Diploma Disease'. Such seminal warnings have gone largely unheeded, leading Lynn Davies (2005) to question: '...the myth that universal formal education automatically creates universal harmony' (p. 358). For the urgent task of assuring human survival, relative peace and considerable co-operation will be required.

Clearly the majority of the world's population has not received formal education appropriate to its needs at particular times and in particular places. According to the definition outlined at the beginning of this paper this is clearly inhumane. The twentieth century, during which the bacillus of mass formal education has spread, has been the most violent in human history and the most destructive of the environment. If the repositories of maximum human talent, the universities, are our best bet in the last chance solution, what evidence is there that they have the wit and wisdom to reverse David Orr's (1994) concern that 'intellectual cleverness' has blunted 'human intelligence' ? We need first to see where the universities are at, and where they seem to be going.

One may begin with a key document from the most recent World Congress on Higher Education held at UNESCO in Paris in 2009. It is titled Trends in Global Higher Education: Tracking an Academic Revolution (Altbach, Reisburg \& Rumbley), and covers the period since the first such Congress in 1998. This turns out to have been a decade of dramatic change; the authors claim it to be the 
most significant since the impact of the German model of the modern university some two hundred years before. This has to do, it seems, with highly disparate massification of higher education, mostly in the more developed regions. Where it is on the way elsewhere is largely to do with the rapid development of private universities. Over 70 per cent of university students are in private institutions in Indonesia, The Philippines and The Republic of Korea, while countries with between 35 and 60 per cent include Malaysia, India and Brazil. How will the private sector respond to the vital role for universities argued here in respect of the survival of humanity? The authors conclude that:

The sector is run mostly on a business model, with power and authority concentrated in boards and chief executives, faculty hold little authority or influence and students are seen as consumers (p. xii).

Globally, the private sector now accounts for over 30 per cent of the total higher education facility and is growing. In association with this trend is a decline in the average qualification of faculty. About 50 per cent of university faculty world-wide have only a bachelor's degree. Along with this, and also affecting higher level public universities in developed countries, is the growth of managerialism which has claimed the time and talent of many previously innovative senior academics. All this is a serious constraint on the likelihood of universities being key players in the survival of humanity, that is to say being the agents of education as a humanitarian response. However, this may have a greater negative effect on one of the three prime functions of the university, teaching, than on the other two: research, and contributing to the well-being of the local community.

The cybernetic revolution has, potentially at any rate, brought together the global and local scales of human operation. The research community constitutes a global knowledge network with a rapidly growing capacity to address local problems, be they political, economic or environmental. At present the potential value is severely constrained by deep disparity of ICT capacity that is widening the global digital divide. A telling prediction in the 2009 UNESCO report is that: 'The academic profession will become more internationally oriented and mobile but will still be structured in accordance with national circumstances' (p. xvii). As global economics also undergoes something of a revolution, new groups of nations are becoming significant players. The so-called BRIC nations (Brazil, Russia, India and China) are being closely followed by the CIVETS (Colombia, Indonesia, Vietnam, Egypt, Turkey and South Africa). It is puzzling why others, such as Malaysia and Venezuela are not included. In all of these, expansion of their higher education sectors and of the middle classes go hand in hand, and their universities are seen primarily as national assets rather than agencies contributing to the resolution of urgent global problems, especially environmental and human survival. Will the global knowledge business with its information hubs impede the imperative of universities serving local communities in the interest of survival?

Clearly the communities most at risk are in the least developed regions where the poorest countries are mostly located. Here, higher education can play a crucial role, as promoted by 'The Task Force on Higher Education and Society' led by The World Bank. Its report in $\mathbf{2 0 0 0}$ was titled Higher Education in Developing Countries: Peril and, Promise the basic conclusion being:

Without more and better higher education, developing countries will find it increasingly difficult to benefit from the global knowledge-based economy (2000, p.9).

The report goes on to emphasise the need for autonomy of universities and other higher education institutions, pointing out that market forces will not provide the kind of innovation required due to dependence on the profit motive. Autonomy will also enable more focus on in-country and especially local research that can enhance the quality of university contribution to the local community. As universities and colleges in less developed countries (LDCs) are enabled to connect with global ICT networks they will be able to elicit support from greater expertise elsewhere. The Task Force recommended the formation of a global volunteer force of scientists, including retirees who would likely be less constrained.

It is important, amid talk of the importance of embracing modern technologies of knowledge acquisition and application, to remember that this requires an underpinning of a sound liberal education. Sheer technical expertise is not enough. It has no intrinsic qualities to make sure that it is applied to the enhancement of humanity in any regard. As the Task Force reminds us, the futurologist Alvin Toffler warned even in 1928 that: 'The illiterate of the $21^{\text {st }}$ century will not be those who cannot read and write, but those who cannot learn, unlearn and relearn'.

\section{Universities, ICTs and Cross-National Co-operation}




\section{Colin Brock}

In view of the urgent need for what the Task Force termed '...a repositioning of higher education in LDCs' (p. 97), what evidence is there of cross-national co-operation to bring about a global/local response to educational need in respect of sustainable survival? Two organisations seeking to address this issue are The Commonwealth of Learning and the UK Open University. The former made a valuable contribution to the 2009 World Conference on Higher Education in the form of a report: ICTs for Higher Education. Given that the formative 1998 UNESCO Conference took place before the global interactive technology of the web really took hold, the potential for global/local initiatives has been massively advanced over the following decade or so. But the report begins with an important user warning:

ICTs are a driver of change, but without good policy and careful planning, can have unintended consequences (p.1).

It is salutary to note that the Commonwealth of Learning (C of L, 2009), based in Vancouver but serving all members of the Commonwealth and indeed beyond, has the stated aim of reaching an audience of new ministers, civil servants and advisers in LDCs. These, unlike most academics are policy-makers and can influence higher education institutions to use ICT in engagement with the community, teaching and administration, as well as in research. The potential of mobile devices is encouraged, and advice is given as to the techno-cultural divide between older academics who have acquired a modest degree of facility and less formally educated new students and community members. C of L says:

Today's students (digital natives) have a different way of approaching and using technologies like cell phones and computers that their teachers (digital immigrants) still need to come to terms with. Educators need to gain an understanding of the virtual worlds that their learners move in so that they can better understand how to interest them in ways that make sense to digital natives (p.3).

In other words, university and other teachers need to connect the global with the local, by adopting the necessary first step by getting to know where their students, who may just be community members, 'are at'. This lies at the heart of one of the UK Open University's projects in Africa, TESSA (Teacher Education in Sub-Saharan Africa). The Commonwealth of Learning is one of the members of a consortium led by the Open University, but also involving the African Virtual University, the BBC World trust and the Open University of Tanzania. It is not sufficient to get only technologically attuned, but also to accommodate the informal knowledge of the trainees of their local community. The quality of schooling anywhere is a direct influence on the quality of higher education. This makes the effectiveness of teachers a crucial component of progress towards meeting the challenges of human and environmental survival. Curricular relevance and community context need to come together. This is achieved in the TESSA project by accommodating the informal knowledge of trainee teachers, including their 'digital native' status. Many are experienced untrained teachers who know how to use their local human and physical environment rather than rely on imported out of context material. Enabling further and higher education to be reachable without necessarily leaving home and creating a brain gain is fundamental to a humanitarian response to educational need. Through appropriate use of ICTs universities and colleges can play a crucial role in averting the kinds of catastrophes predicted by Brizony and Martin, or at least adjusting to them. This is what the Commonwealth of Learning refers to as 'community engagement' (p.8).

At the heart of this ICT enabled enhanced experience is 'Bioinformatics' offered by 153 universities in North America but only 8 in Africa. Top - level developing countries have begun to offer distance learning programmes in this and related fields in Brazil, India and South Africa. According to the C of L, the Sunspace Project based at Stellenbosch University, with the help of NASA: '...has the potential to provide a GIS (Geographical Information System) for strengthening the development of Africa' (p.12). Such higher-level informatics is of little use if the pedagogy of its introduction at community level is of poor quality, or even worse, inappropriate - as much of colonially-derived education has already been. According to the $\mathrm{C}$ of $\mathrm{L}$, four key reasons for failure to connect poor communities with aspects of ICT that would assist their development for survival are: the failure to review student needs before installing; imposing systems 'top down' without consultation; using inappropriate content from other regions or cultures; and low quality content (p.24).

\section{Universities and Partnerships}

The 1998 UNESCO World Conference on Higher Education came to the main conclusion that universities and other HEls should form partnerships with other components of the formal systems such as primary and secondary schools, and the non- informal elements such as NGOs. This was nearly a decade after the 1990 UNESCO-sponsored Conference at Jomtien, largely concerned with 
promoting Universal Primary Education (UPE), had called for new partnerships at local level across all forms of education operating in communities. But, during the 1990s, international donor policy had swung sharply behind the support of UPE to the relative neglect of external funding for secondary schooling, universities and other HEls in less developed countries. The seemingly crucial and overlooked imperative in this otherwise laudable initiative was the fundamental need to work upward from local initiative, rather than have poorly funded top down reforms and projects operated at a national level. Nonetheless, latent local potential began to be realised, and was the subject of an international workshop held at Langkawi, Malaysia in March 1997 which was convened by the Commonwealth Secretariat to consider the outcome of its commissioning in 1995 of a number of country studies to highlight initiatives that had emerged in ten locations within Botswana, Ghana, India, Malaysia, New Zealand, The South Pacific, Sri Lanka, Tanzania, Trinidad and Tobago, and Zambia. This led in turn to the publication of Partnerships in Education for All: The Role of Higher Education in Basic Education (Leach, 2003). Meantime in 1996, an EFA meeting in Amman had in effect alluded to the need for the support of universities in four areas fundamental to the realisation of EFA: more local content in the curriculum; more non-formal education; more local information to be gathered in data bases; better inter-sector links between education, health and environment.

One year prior to the publication of the Commonwealth Secretariat Report in 2003, Pyle and Forrant had published their book: Globalisation, Universities and Issues of Sustainable Human Development in which they discuss constraints faced by universities in promoting sustainable development. One, they suggest, is the so-called 'triple helix' of Etzkowitz (2000), which places universities in relationships with government and industry. There may have possibilities for social entrepreneurships within what he calls 'entrepreneurial pathways of university development' (Pyle \& Forrant, p. 17). Such arrangements can impede the independence and integrity of universities. In developing countries they also suggest constraints on relationships with society, especially rural, that arise from universities being based on colonially derived models. The shift in aid funding from higher education to primary education following 'Jomtien' in 1990 hadn't helped either, though that has since become more balanced. Nonetheless Pyle and Forrant conclude, in the political and economic climate of the time:

...the university's ability to provide broad-based education and increase the quality of social, intellectual and economic life for communities and nations becomes hostage to liberalisation, privatisation and the chase for the research dollar (p.24).

Nonetheless, they proceed to include a number of case studies and themes where universities have attempted to play their part in local or regional partnerships, including one in Malaysia.

In this case study M. Sirat (2002) discusses: 'Managing the Interface with the Region: The Case of Universiti Sains Malaysia, Pulau Pinang, Malaysia'. It is claimed that 'the university is managing its interface with the geographic region, particularly as it applies to purposeful community service' (p.194). It was decided to establish two branch campuses, one for medical sciences in 1979 on the east coast and another in 1986 for engineering in the north of the country. In defining the community to which any university seeks to relate it is suggested that at least four things be taken into account:

...first, the relationship between the university and its physical surroundings as influenced by the historical and institutional context; second, the different scales at which attributes or impacts of the university should be measured and assessed; third, the different geographic scale of territory over which the university provides services; and fourth, the perceptions held by the institutions and its management of the local community which is identified in institutional plans and through related activities (p.203).

In examining these issues the author concentrates on the 'Transkrian Engineering Campus' which 'straddles the three contiguous states - Kedah, Pulau Pinang and Perak - that comprise Malaysia's northern region'. In addition to increasing access to academic and technical training, service to the local community has been developed in the form of sports facilities, information technology and other facilities.

In Leach (2003) there is another example from Malaysia, this time focusing on basic education. In this case the University of Science Malaysia in the state of Penang (Piew, Kassim, Kim and Abdullah, pp. 84-103). The Basic Education Research Unit (BERU) had its origins in this university in 'Project InSPIRE' leading to an initiative arising from Jomtien and EFA in 1990. Part of this was the Centre for Extension and Continuing Education which developed the following: a 'Village Adoption Programme', veterinary and plant clinic services, 'Farmers Days', a 'Small Business Development Scheme', and a 'Young Entrepreneurs Programme'. In addition to these formal innovations, a range of non-formal initiatives has been carried out in association with local NGOs. All this is in the interests of empowerment and sustainable development. 


\section{COLIN BROCK}

Such responses were recognised to different degrees in the other nine case-studies of the Commonwealth Secretariat, as were constraints to their being met. These constraints were listed as: lack of appropriate structures; limited impact on basic education policy and delivery; lack of links with those involved in the delivery of basic education, especially primary education; lack of collaboration between HEls on initiatives in basic education; inadequate information about on-going higher education activity in the field of basic education; lack of empirical work in the field of basic education (Leach, 2003, pp. 14-15). Not surprisingly, following descriptions of the ten cases the report makes a number of recommendations to address the constraints listed above, namely: greater flexibility between HEls, communities and their schools; more interaction and co-operation between HEls with regard to local partnerships and other relevant initiatives; the creation of local databases to inform initiatives; more appropriate capacitybuilding with regard to effecting local partnerships; and more dynamic policies and management structures for HEls to enable them to act in this radical way. In other words this means universities and HEls becoming a lead agent in education as a humanitarian response.

\section{Conclusion}

It is clear from the discussion above that for universities and other HEls to play their optimum role as partners in meeting the challenges of human survival and sustainable development, there needs to be radical and rapid reform. Post-secondary sector institutions are vital to the rapid creation and operation of partnerships with other sectors and forms of education to enable what the UK government recognised as 'thinking and learning in a profoundly different way'. To date that government has shown no signs of doing so, and it is highly likely that other governments will be equally reactionary. They are fixated on cross-national and even intra-national competition rather than imaginative reform both curricular and administrative in the interests of saving the species and the planet.

Nonetheless, it behooves the higher education sector with its relative independence and sophisticated ICT capabilities to make a move before it is too late. In any case, grandiose national scale initiatives will not work. It is at the local level that partnerships, with post-secondary, preferably university, institutions at the hub, need to be established. In the conclusion of my book Education as a Global Concern (Brock, 2010), have put it thus:

National and local political authority over education, the 'authority' that determines the extent to which the vital contribution of education can be realized, is not going to go away. Instead that authority must itself be educated to the fact that the kind of reform required at every locality within its territory is in its own best interest. Figure 6.1 [see Figure 1] illustrates the way in which partnerships across the sectors of formal education, as well as with the non-formal and informal dimensions of learning could be made (p.145).

Figure 6.1 in the above quotation is reproduced as Figure 1 below. With respect to the circle marked 'SCHOOLS', the 'EHR' Curriculum refers to a section earlier in the text whereby it is suggested that: a) core subjects such as mathematics, language and science should be conducted in such a way as to engage technical skills and be exemplified as far as possible through the local context; b) the remaining liberal education subjects such as geography, history and literature should also, at least in part, be conducted in such a way as to accommodate some of the technical skills as well as the local context.

It is at this geographical scale that the seeds of sustainable development need to be sown. That is to say, in a community context in which to grow. The more developed the society the more likely the situation of a university within or near the community is likely to be. In less developed, and/or remote locations, the university or other form of HEI may be far away but it can play its part through appropriate ICT input both administrative and curricular. This would include the vital element of locally generated research and data enabled by the secondment of a small number of appropriate staff and/or through a sufficiently equipped NGO such as 'ActionAid' or 'Practical Action'. Such local input should ensure the degree of appropriateness that characterizes a humane response, something akin to the Freirean concern for intellectual as well as practical ownership of the educational process. As Richard Schaull put it in his foreword to Paulo Freire's Pedagogy of the Oppressed (1972), education then becomes 'the means by which men and women deal critically and creatively with reality and discover how to participate in the transformation of their world (pp. 13-14).

Realisation of the urgency of this liberation has increased greatly since the days of Freire's pioneering work, at least by radical and well-informed thinkers such as Brizony, Martin and Orr, quoted above. But it has not yet reached the majorities in developed and developing countries alike in their local communities due to the perverse 
priorities of governments and multi-national agencies that depend on them for funding. Universities can, and must, use their greater understanding and ICT capacities to take the lead in enabling communities to have a chance to save themselves and their environment.

\section{References}

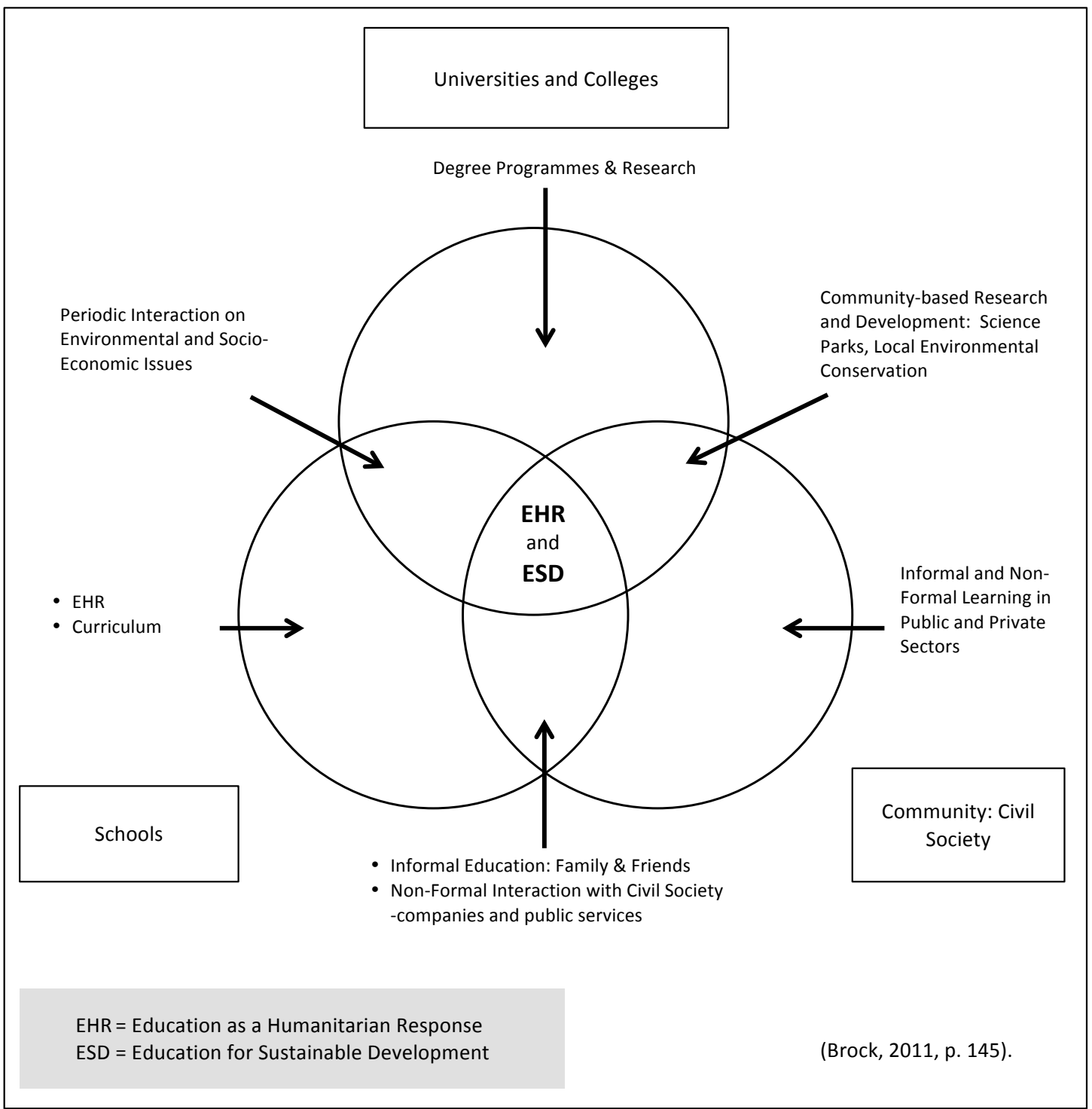

Figure 1: Integrated Education with Locale Specific and Global Humanitarian and Environmental Sustainable Perspectives, (Brock, 2011, p. 145). 
Aldrich, R. (2010). Education for survival: A historical perspective. History of Education, 39(1), 1-14.

Brizony, P. (2011). Science: The Definitive Guide. London: Quercus.

Crossley, M., Bray, M., and Packer, S. (2011). Education in Small States: Policies and Priorities. London: The Commonwealth Secretariat.

Bray, M. \& Murray Thomas, R. (1995). Levels of comparison in educational studies: Different insights from different literatures and the value of multilevel analyses. Harvard Educational Review, 65(3), 472-490.

Brock, C. (1984). Scale, isolation and dependence. London: The Commonwealth Secretariat.

Brock, C. (2010). Spatial dimensions of Christianity and education in Western European history with legacies for the present. Comparative Education, 46(3), 289-306.

Brock, C. (2011). Education as a global concern. London: Continuum Books.

Brock, C. (2012). Universities, independence, internationalism and integrity. In F.L Segrera \& H. Grimaldo (Eds.) The Internationalisation of Higher Education Worldwide: Main Trends and Challenges. Bogota: Planeta (forthcoming).

Commonwealth of Learning. (2009). ICTs for higher education. Paris: UNESCO.

Davies, L. (2005). Schools and war: Urgent agendas for comparative and international education. Compare, 35(4), 357-372.

Dodgshon R. A. (1987). The European past: Social evolution and the social order. Basingstoke: Macmillan.

Dore, R. (1976). The diploma disease. London: Allen and Unwin.

Elliott, P. \& Daniels, S. (2010). 'No study so agreeable to the youthful mind': Geographical education in the Georgian grammar school. History of Education, 39(1), 15 - 34.

Etzkowicz, H. and Leydesdorff, L. (2000). The Dynamics of Innovation: From National Systems and 'Mode 2' to a Triple Helix of University-Industry-Government Relations, Research Policy, 29, 109-123.

Griffin, C.R. (2001). The mediation of market-related policies for the provision of public second-Level education: An international comparative study of selected locations in England, Ireland and the USA. Unpublished D.Phil. Thesis: University of Oxford.

Hamnett. C. \& Buttler, T. (2011). Geography matters: The role distance plays in reproducing educational inequality in east London. Transactions of the Institute of British Geographers, 36(4), 470-500.

Hopper, E. (1968). A Typology for the classification of education systems, Sociology, 2, 29-46.

Leach, F. (Ed.) (2003). Partnerships in Education for All: The role of higher education in basic education. London: The Commonwealth Secretariat.

Mabogunje, A. (1980). The development process: A spatial perspective. London: Hutchinson.

McKie, R. (2011). Forget conflict: Science is delivered by collaboration and shared values. The Observer, 24 July, p. 31.

Mallinson, V. (1980). The western European idea of education. Oxford: Elsevier. In J. Martin (2011) 'Fasten Your Seatbelts, There's Turbulence Ahead', Oxford Today, 23(3), 28-30.

Orr, D. W. (1994). Earth in mind: On education, environment and the human prospect. Washington DC: Island Press.

Oxenham, J. (Ed.) (1984). Education versus qualifications. London: Allen and Unwin.

Piew, L. S., Kassim, M, Kim, P. L. \& Abdullah, A. C. (2003). Malaysia. In Leach (op cit, pp.84-103)

Pyle, J. L. \& Forrant, R. (2002) Globalization, universities and issues of sustainable human development. Cheltenham, UK: Edward Elgar.

Robinson, K., Sir (2006). Do schools kill creativity? Los Angeles: TED Lecture, Available at http://www.ted.com/talks/ken_robinson_says_schools_kill_creativity.html

Schaull, R. (1972). Foreword. In Freire, P. The Pedagogy of the Oppressed. Harmondsworth: Penguin.

Sirat, M. (2002). Managing the interface with the region: The case of Universiti Sains Malaysia, Pulau Pinang, Malaysia. In J.L Pyle \& R. Forrant, op.cit. pp. 194-211.

Task Force for Higher Education and Society. (2000). Higher education in developing countries: Peris and promise,.Washington: The World Bank.

UNESCO. (2011). Education for Sustainable Development. Paris: UNESCO.

UNESCO. (2009). Trends in global higher education: Tracking an academic revolution. (Ed. P. Altbach, L. Reisberg \& L.E. Rumbley. Paris: UNESCO. 